\title{
Academia Unplugged: Understanding the Intersection of Gender and Race in the Trajectories of Black Women Academics at UKZN
}

\author{
Aradhana Ramnund-Mansingh \\ ORCID iD: https://orcid.org/0000-0003-1995-6849
}

Mariam Seedat-Khan

ORCID iD: https://orcid.org/0000-0001-9056-2282

\begin{abstract}
This study sought to explore the career trajectories of Black South African women academics from the University of KwaZulu-Natal, South Africa. Ten in-depth interviews were conducted at five UKZN campuses. Participants were invited to recount their lived experiences in the academy, which continue to include political vicissitudes of race and gender. Existing scholarship on challenges faced by Black women is palpable; the South African landscape is distinctive, with complex intersections from the oppressive apartheid state followed by the 2004 post-apartheid higher education transformation. Prominent themes that developed, when examining race and gender, included institutional culture, the old boys' network ${ }^{1}$ role overload and academic bullying. The theoretical framework that underpinned this study is social constructivism with a precise focus on intersectionality. Intersectionality provided context to the racial and gendered experiences of women in the academy. The South African government recognises intersectional experiences
\end{abstract}

${ }^{1}$ Historically, higher education institutions were predominantly made up of male academics who formed their social networks and made gender parity at any level, an elusive imperative. 
via legislation ${ }^{2}$ that addresses historical race and gender incongruences.

Notwithstanding the focus on intersectionality, experiences of exploitation continue to be perpetrated against Black women in the academy. While the legislation includes race and gender targets which play a critical role in transformation, Black women academics faced intersectional gendered challenges in apartheid-style 'bush colleges' ${ }^{3}$. This continued in a post-apartheid society where they are subject to gender and racial prejudices. The empirical evidence seeks to espouse Black women in academia by propositioning a framework on their historical experience and presenting the bearing that transformation has had on them exclusively. Black women, specifically, continue to be imperilled to innumerable career and personal adversities.

Keywords: Old boys' network, institutional culture, bush colleges, academic bullying, South Africa, higher education, Black, women

\section{Introduction}

The South African ${ }^{4}$ Higher Education ${ }^{5}$ story is unique. Apartheid separated people according to race. This division remains an inherent part of South African society despite the demise of apartheid. Post-apartheid leadership responded to the plight of marginalised Black ${ }^{6}$ women in the academy, calling

${ }^{2}$ Legislation, including the Employment Equity Act 55 of 1998 designed to encourage racial transformation.

3 'Bush colleges such as the University of Zululand, University of the North, Fort Hare University, Vista University, University of Venda, University of Western Cape, University of Transkei, University of Durban Westville and the Medical University of South Africa were designed to divide recipients racially. Typically differentiating between the quality of education and resources offered, based on the structures and hierarchies created by the architects of apartheid.

${ }^{4}$ Hereafter referred to as SA.

${ }^{5}$ Hereafter referred to as HE.

${ }^{6}$ Defined in the Employment Equity Act 55 of 1998 which states that 'Black people' is a generic term which means Africans, Coloureds, and Indians and included provisions to ensure that they must have been South African citizens before 1994. 
for the operation of race and gender enfranchisement national imperatives in HE. The definition of Black women is defined according to the guidelines in the Employment Equity Legislation No. 55 of 1998. Black women who participated in this study include African, Indian and Coloured academics. This article explores the career trajectories of historically marginalised Black women academics via their lived experiences in the academy at the University of KwaZulu-Natal. ${ }^{7}$ The study begins with a background to HE in SA, followed by a theoretical framework on social constructivism and intersectionality, tailed by the methodological approach. This discussion and analysis are guided by the intersectional approach, adopting four key themes, a) institutional culture; b) the old boys' network; c) role overload; and d) academic bullying.

\section{A Background to $\mathrm{HE}$ in SA}

The establishment of the National Commission on HE (NCHE) in 1995 studied global representations of HE to improve SA models. They found that universities globally struggled tackling gender and racial equality. A combination of legislation, include the Higher Education Act (No of 101 1997); Basic Conditions of Employment Act (No 75 of 1997), Employment Equity Act (No 55 of 1998), Skills Development Act (No 97 of 1998) and the Labour Relations Act (No 66 of 1995) served an essential role in transforming HE. The HE Act (No 101 of 1997, amended in 2010) failed to deliver provision for gender structures. The Employment Equity Act 55 of 1998 was promulgated to eliminate discrimination in employment policy, yet it failed to make gender provisions. The patriarchal social construction of unequal HE directed by apartheid law impacting education subscribed to the injustice of reserving high-paying skilled jobs for White English and Afrikaans groups, and lowpaying, labour-intensive work for Black groups. The Bantu Education Act (No 47, of 1953); The Extension of University Education Act (No 45, of 1959); The Coloured Persons Education Act 47 of 1963 and The Indians Education Act (No 61 of 1965), subjugated Black South Africa, forcing apartheid state laws, resulting in an obviously disproportionate education system. Legislation was initiated at Basic Education level, advancing to $\mathrm{HE}$, leading to the incongruency in education underpinned by apartheids complex-gendered history. Only $2.3 \%$ of all Black teachers have a university degree and $82 \%$ of

${ }^{7}$ Hereafter referred to as UKZN. 
Black teachers have no high school diploma (Boddy-Evans, 2020). These vestiges continue to linger in higher education today.

Table 1: Break-down of government funding per race category and teacher/ child ratio during apartheid

\begin{tabular}{|l|l|l|l|l|}
\hline & $\begin{array}{l}\text { Compulsory } \\
\text { school age }\end{array}$ & $\begin{array}{l}\text { Government } \\
\text { per child } \\
\text { funding } \\
(\mathbf{1 9 7 6}) *\end{array}$ & $\begin{array}{l}\text { Government } \\
\text { per child } \\
\text { funding } \\
(\mathbf{1 9 8 2}) * *\end{array}$ & $\begin{array}{l}\text { Teacher/child } \\
\text { ratio*** }\end{array}$ \\
\hline White & 16 & R644,00 & R1 211,00 & $1: 18$ \\
\hline Indian & 15 & R189,00 & Not available & $1: 24$ \\
\hline Coloured & 15 & R139,00 & Not available & $1: 27$ \\
\hline Black & 13 & R42,00 & R146,00 & $1: 39$ \\
\hline
\end{tabular}

*Villette (2016) ** Boddy-Evans (2020)

*** Ocampo (2004)

\section{Historically Black Universities}

Bush colleges were explicitly reserved for Black people and classified into Universities and Technikons ${ }^{8}$ (Cloete et al. 2004). The table below indicates the number of Universities and Technikons established according to race classifications.

Table 2: Number of Universities and Technikons established according to race classifications

\begin{tabular}{|l|c|c|}
\hline \multicolumn{1}{|c|}{ Race } & Universities & Technikons \\
\hline White & 11 & 8 \\
\hline Coloured & 1 & 1 \\
\hline Indian & 1 & 1 \\
\hline Black & 8 & 5 \\
\hline
\end{tabular}

${ }^{8}$ In South Africa, it was an institution offering technical and vocational education at tertiary level. In the $2004 \mathrm{HE}$ structure, Technikons became Universities of Technology. 
The standard of education was deliberately diluted to subjugate Black people into compliance. Specific Black people were selected to work with apartheid officials and compensated; making a significant contribution to the maintenance and success of the apartheid socio-political agenda. The 'useful graduates' were Black teachers to be used in the Black school system and the Black civil servants involved in the racially divided public service of South Africa (Cloete et al. 2004).

The institutional structural location of UNITRA as a lower grade Bantustan ${ }^{9}$ University situated in the capital of the homeland Transkei had two significant implications for the institution in the era of apartheid. First, it had a captive student market. Apartheid restricted the educational mobility of students based on racial and tribal ancestry. Second, as a Bantustan university, UNITRA was not a financially autonomous institution (Habib 2001, cited in Cloete 2004: 46).

Apartheid state officials undermined the capability of these HE institutions and failed to foresee them triggering political activism that would ultimately give rise to the collapse of the apartheid state.

Table 3: List of Historically Black Universities during apartheid

\begin{tabular}{|l|l|}
\hline \multicolumn{2}{|c|}{ Bush Colleges } \\
\hline Historically Black Universities for Africans ${ }^{\mathbf{0}}$ \\
\hline $\begin{array}{l}\text { Medical University of South Africa } \\
\text { (MEDUNSA) }\end{array}$ & HBU for Africans \\
\hline University of the North & HBU for Africans \\
\hline Vista University & HBU for Africans \\
\hline University of Zululand & HBU for Africans \\
\hline Historically Black Universities for Indians \\
\hline
\end{tabular}

9 'Homelands' is defined as a Bantustan and was a territory set aside for Black inhabitants of South Africa and South-West Africa (now Namibia), as part of the policy of apartheid.

${ }^{10}$ The Population Registration Act (No. 30 of 1950) defined Africans as native Black people of South Africa. 
Gender and Race in the Trajectories of Black Women Academics

\begin{tabular}{|c|c|}
\hline University of Durban-Westville (UDW) & HBU for Indians \\
\hline \multicolumn{2}{|c|}{ Historically Black Universities for Coloureds } \\
\hline University of the Western Cape & HBU for Coloureds \\
\hline \multicolumn{2}{|c|}{ Historically Black Universities for Africans } \\
\hline University of Transkei & $\begin{array}{l}\text { HBU Homeland } \\
\text { Universities }^{11} \\
\end{array}$ \\
\hline North-West University & HBU Homeland Universities \\
\hline University of Venda & $\begin{array}{l}\text { HBU Homeland } \\
\text { Universities }\end{array}$ \\
\hline University of Fort Hare & $\begin{array}{l}\text { HBU Homeland } \\
\text { Universities }\end{array}$ \\
\hline
\end{tabular}

Table 4: List of Historically Black Technikons during apartheid

\begin{tabular}{|c|c|}
\hline \multicolumn{2}{|l|}{ Apartheid Technikons } \\
\hline \multicolumn{2}{|l|}{ Historically Indian Technikon } \\
\hline ML Sultan Technikon & Historically Indian Technikon \\
\hline \multicolumn{2}{|c|}{ Historically Coloured Technikon } \\
\hline Peninsula Technikon & Historically Coloured Technikon \\
\hline \multicolumn{2}{|l|}{ Historically African Technikons } \\
\hline Mangosuthu Technikon & Historically African Technikons \\
\hline Technikon Northern Transvaal & Historically African Technikons \\
\hline \multicolumn{2}{|c|}{ Historically African Homeland Technikons } \\
\hline Border Technikon & Historically African Technikons (TBVC) \\
\hline Eastern Cape Technikon & Historically African Technikons (TBVC) \\
\hline North-West Technikon & Historically African Technikons (TBVC) \\
\hline
\end{tabular}

\section{Table 5: List of Historically White Afrikaans medium Universities during apartheid}

\begin{tabular}{|l|l|}
\hline \multicolumn{2}{|c|}{ Apartheid Universities } \\
\hline Historically White Afrikaans Medium Universities \& Technikons \\
\hline University of the Orange Free State & Afrikaans Medium For Whites \\
\hline Otchefstroom University & Afrikaans Medium For Whites \\
\hline University of Pretoria & Afrikaans Medium For Whites \\
\hline
\end{tabular}

${ }^{11}$ Transkei, Bophuthatswana, Venda and Ciskei (the TBVC countries). 


\begin{tabular}{|l|l|}
\hline Rand Afrikaans University & Afrikaans Medium For Whites \\
\hline University of Stellenbosch & Afrikaans Medium For Whites \\
\hline University of Port Elizabeth & Dual Medium For Whites \\
\hline Free State Technikon & Afrikaans Medium for Whites \\
\hline Vaal Triangle Technikon & Afrikaans Medium for Whites \\
\hline Pretoria Technikon & Afrikaans Medium for Whites \\
\hline Port Elizabeth Technikon & Dual Medium for Whites \\
\hline
\end{tabular}

\section{Table 6: List of Historically White English medium Universities during apartheid}

\begin{tabular}{|l|l|}
\hline \multicolumn{2}{|l|}{ Historically White English-Medium Universities \& Technikons } \\
\hline University of Cape Town & English Medium For Whites \\
\hline University of Natal & English Medium For Whites \\
\hline Rhodes University & English Medium For Whites \\
\hline University of the Witwatersrand & English Medium For Whites \\
\hline University of South Africa (UNISA) & $\begin{array}{l}\text { English Medium Distance learning for } \\
\text { Whites }\end{array}$ \\
\hline Technikon Witwatersrand & English Medium for Whites \\
\hline Cape Technikon & English Medium for Whites \\
\hline Natal Technikon & English Medium for Whites \\
\hline Technikon South Africa (TSA) & $\begin{array}{l}\text { English Medium Distance learning for } \\
\text { Whites }\end{array}$ \\
\hline
\end{tabular}

Historically white universities were separated into Afrikaans and English institutions. Afrikaans-medium universities were aligned with the government, which impacted on their institutional culture. Access to scholarship remained censored under apartheid, designed to support exclusionary socio-political and economic structures. These universities excluded Black students and academic staff in compliance with apartheid. English-medium universities, the so-called 'liberal universities', experienced conflict when welcoming Black students and staff. They were determined in their pursuit for academic freedom and 'publicly declared that 'academic freedom in SA was dead' because of apartheid restrictions on teaching materials, student admissions and the selection of academics' (Cloete et al. 2004: 42). 


\section{Post-Merger Universities and Technikons}

\section{Table 7: Merged institutions post 2004}

\begin{tabular}{|l|l|}
\hline Merged Institution post-2004 & Includes \\
\hline University of KwaZulu-Natal - & UDW - Westville Campus - \\
UKZN & Historically Indian \\
& UND - Natal University - Howard \\
College - White English & UNP- Natal University - \\
& Pietermaritzburg Campus - White \\
& English \\
& Medical School ${ }^{12}$ - Umbilo Campus - \\
& White English \\
& Edgewood College of Education - \\
& White English \\
\hline University of Cape Town - UCT & White English \\
\hline University of Fort Hare - UFH & HBU for Africans in the Homelands \\
\hline North-West University - NWU & $\begin{array}{l}\text { Potchefstroom University Campus - } \\
\text { White Afrikaans }\end{array}$ \\
& University of North-West Campus - \\
& White Afrikaans \\
\hline Nelson Mandela Metropolitan & University of Port Elizabeth Campus - \\
University - NMMU & White English and Afrikaans \\
& Port Elizabeth Technikon Campus - \\
White English and Afrikaans
\end{tabular}

12 In 1951, the University of Natal's Faculty of Medicine opened on a completely separate campus to the rest of the English White institution. 'Its purpose was to provide a high standard medical training program for black (including African, Indian and Coloured) students, though in a racially segregated educational facility, who would become fully qualified doctors to serve their people in a racially segregated medical service' (Noble 2018). 


\begin{tabular}{|c|c|}
\hline University of Limpopo & $\begin{array}{l}\text { MEDUNSA Campus - HBU for } \\
\text { Africans } \\
\text { University of the North Campus - } \\
\text { HBU for Africans }\end{array}$ \\
\hline Venda University (UNIVEN) & HBU for Africans in the Homelands \\
\hline University of Western Cape (UWC) & Historically for Coloured People \\
\hline University of Witwatersrand & White English \\
\hline Zululand University - UNIZULU & HBU for African People \\
\hline $\begin{array}{l}\text { Walter Sisulu University for } \\
\text { Technology- WSU }\end{array}$ & $\begin{array}{l}\text { Border Technikon Campus - Africans } \\
\text { in the Homelands } \\
\text { Eastern Cape Technikon Campus - } \\
\text { Africans in the Homelands } \\
\text { University of Transkei Campus - } \\
\text { HBU for Africans in the Homelands }\end{array}$ \\
\hline $\begin{array}{l}\text { Cape Peninsula University of } \\
\text { Technology - CPUT }\end{array}$ & $\begin{array}{l}\text { Cape Technikon Campus - White } \\
\text { English } \\
\text { Peninsula Technikon Campus - } \\
\text { Historically Coloured Technikon }\end{array}$ \\
\hline $\begin{array}{l}\text { Durban Institute of Technology- } \\
\text { DUT }\end{array}$ & $\begin{array}{l}\text { M.L. Sultan Campus - Historically } \\
\text { Indian Technikon } \\
\text { Natal Technikon - White English }\end{array}$ \\
\hline $\begin{array}{l}\text { Tshwane University of Technology- } \\
\text { TUT }\end{array}$ & $\begin{array}{l}\text { Pretoria Technikon Campus - White } \\
\text { Afrikaans } \\
\text { Technikon North-West Campus - } \\
\text { White Afrikaans } \\
\text { Technikon Northern Gauteng Campus } \\
\text { - Historically African Technikon }\end{array}$ \\
\hline University of Johannesburg - UJ & $\begin{array}{l}\text { Rand Afrikaans University Campus - } \\
\text { White Afrikaans } \\
\text { Witwatersrand Technikon Campus - } \\
\text { White Afrikaans }\end{array}$ \\
\hline University of South Africa-UNISA & $\begin{array}{l}\text { University of South Africa - Distance } \\
\text { learning Institute } \\
\text { Technikon South Africa - Distance } \\
\text { learning Institute }\end{array}$ \\
\hline Vaal University of Technology & White Afrikaans \\
\hline Central University of Technology & White Afrikaans \\
\hline $\begin{array}{l}\text { Mangosuthu University of } \\
\text { Technology }\end{array}$ & Historically for African People \\
\hline
\end{tabular}




\section{Black Women Academics Transition in HE 1994 - 2004}

The impact of an apartheid education significantly influenced the number of Black women in academia pre- and post-apartheid.

Black women are traditionally considered responsible for the house, children, and people in general, compared to black men who are considered responsible for accomplishing their goals outside the house in war, hunting, politics, and paid work. Unfortunately, precisely because of these prejudices, women are, from their youth, discouraged to pursue higher levels of education, to work outside the house, and especially to enter traditionally male industries, to advance in their careers, or to compete for management positions (Poloski 2001: 3).

Women experienced a triple oppression of race, gender, and class. Education for Black women was not prioritised; resulting in high levels of illiteracy, resulting in restricted access to HE. The Black women detected in bush colleges were marginal, found in the feminised faculties of nursing and teaching. They were subjected to role overload of teaching and administration expectations, which persisted post-apartheid (Cloete et al. 2004). The gender question indicated that,

The women at the historically white universities felt that racism and sexism were linked, but racism seemed to be the overriding variable. Certain of these women at HBU's had opted for Afrikaans-speaking universities as opposed to the liberal English universities (Potgieter 2002: 28).

This choice of institution is a signal of exactly how the intersection of race, gender, class, culture and language influence Black women academics. HBU's failure to comply with race and gender transformation has suffered the loss of prominent academics to historically White and Afrikaans-medium universities. Potgieter's (2002) study criticises HBUs for ineffective leadership and a lack of professionalism. Potgieter (2002: 29) presents the case of a Harvard University graduate, Black woman $\mathrm{PhD}$ academic at an $\mathrm{HBU}$, forced to resign after conflict regarding role overload with male colleagues and her line manager. Women at HBUs were subject to patriarchal practices, and 
mindsets, often forced to 'face particularly difficult choices between the 'traditional' and the 'modern' role, which can lead to a crisis of identity, uncertainty, confusion and conflict' (Speedy 2003: 4). Prof. Moutlana was one of three Black women vice-chancellors among $23 \mathrm{HE}$ institutions in South Africa in 2004. Prof. Moutlana's success story was not without challenges.

The professional socialisation of women takes place within a system of power and inequality and as such, has substantial aspects that have to do with the reproduction of various forms of inequalities. Women in top management positions usually get their first view and feel this reproduction of inequality when recruited into the institution (Moutlana 2001: 1).

\section{Theoretical Context}

Intersectionality within the South African HE is a judicious structure that provides guidelines for scholars to ascertain how past and present institutional structures and seats of power penetrate the academy and impact on Black women in particular. Intersectionality cogitates that innumerable forms of social hierarchy, such as gender and race, which do not function in isolation from economic, political, cultural, and social intersections in society remain central. To unpack the intersections of gender and race in the trajectories of Black women academics, a series of intersecting factors are recognised; these include, but are not limited to patriarchy, culture, marital status and social class. Intersectionality is rooted in historical and social oppression postulating a framework offering rationalizations of gender and race to understand and analyse the experiences of Black women. Intersectionality and identity construction are lifelong processes made possible by socialisation.

Social processes form an identity; once crystallised, it is maintained, modified, or even reshaped by social relations. The social structure determines the social processes involved in both the formation and the maintenance of identity. Conversely, the identities produced by the interplay of the organism, individual consciousness, and social structure react upon the given social structure, maintaining it, modifying it, or even reshaping it. Societies have histories in the course of which specific identities emerge; these histories are, 
however, made by men with specific identities (Berger \& Luckmann 1979: 194).

Individual lived experiences informing identities, gender, age, sexuality, race, and social class are 'socially bestowed identities' derived from a series of discourses ${ }^{13}$. They intersect at all levels throughout the individual's life.

Our identity is constructed out of the discourses culturally available to us, and which we draw upon in our communications with other people. A person's identity is achieved by a subtle interweaving of many different threads (Burr 2007: 106).

The discourse of science and masculinity matches scientists as predominantly male; and caregivers as principally women. Burr (2007) differentiates between gender role discourses and illustrates how socialisation plays a role in the career paths of Black women academics. While discourses on masculinity indicate that men take control, lead, make decisions, are aggressive and unemotional, feminine discourses identify emotionality, illogicality, and intuitiveness as traits that may make science a challenging career choice for a woman. Men are described as strong, arrogant, intelligent, ego-driven, powerful, dominant, assertive, single-tasking, focused, competitive, stubborn, physical, self-righteous, and direct. These traits are required for traditional patriarchal leadership models embedded in institutional culture.

Women in leadership positions are described as multi-tasking, emotional, empathetic, strong, intuitive, compassionate, relationship building, verbal, consensus building, and collaborative. Feminine leadership values are fast becoming acceptable leadership models globally (Burr 2007). Rosabeth Moss Kanter's illustrates gendered structures by showing how 'organisational structure forms peoples sense of themselves and their possibilities' (Kanter 1977: 3). She identified that structure forms the rules of social organisations and relationships therefore behaviour displayed by men and women were situation specific and not gender specific. Kanter (1977) concludes that the intersectionality of race and gender did not play a role in career trajectories' success. Gendered institutions refer to 'a persistent constellation of practices,

13 'A discourse provides a frame of reference, a way of interpreting the world and giving it meaning that allows some objects to take shape' (Burr 2007: 105). 
power relations, norms, interactional dynamics and ideologies surrounding social phenomena' (Aulette, Wittner \& Blakely 2009: 66) and collectively offers credence to the existence of the old boys' network. In this explication, men band together and show support for one another and exercise their power over women. The rules of this network make the inclusivity of women impossible. Commonly accepted golf days and late-night social engagements deliberately exclude women with familial responsibilities.

Kossek and Lambert (2005) and Berger and Luckmann (1979) offer an explanation of resocialisation, which includes work, marriage, and parenthood, 'the process by which persons acquire the knowledge, skills, and dispositions that make them more or less able members of their society' (Kossek \& Lambert 2005: 290). Significantly, motherhood presents a challenge for formally employed women who have to engage in domestic unpaid work. Aulette, Wittner and Blakely (2009: 161) found that housework and emotional labour are 'invisible'. 'It is seen as a natural part of women's nurturing and caretaking, something to be expected but not recognised'. It is not uncommon for women to work 18 hours a day. Lorber (1994: 62) states that 'gender inequality - the devaluation of 'women' and the social domination of 'men' - has social functions and social history'. Traditionally when men returned from hunting, which was considered meaningful work, it was celebrated; however, unpaid household work by women is viewed as 'women's work' and its value decreases. This intersection into the familial home further compromises women's professional obligations. Intersectionality advances that gender is interconnected with socially constructed categories and,

It helps us see that no social category is homogenous; the categories to which someone belongs places them in a complex system of domination and subordination, and the effects of the categories a person occupies cannot simply be added together to obtain some total. Each of us derives varying amounts of penalty and privilege from the multiple systems of oppression that frame our lives (Seedat-Khan $e t$ al. 2016: 122).

Intersectionality offers context and frames an understanding of distinctive identities that women experience.

The notion that identity is formed by interlocking and mutually rein- 
forcing vectors of race, gender, class, and sexuality have pervaded Black feminist scholarship for decades. The women-of-colour critique of conventional feminism's essentialism emphasised the disconnect between feminism's claims to speak for all women and feminism's perennial inattention to racial, ethnic, class, and sexual difference(s) (Nash 2008: 3).

Carastathis (2014) recognise that women's identities are located in a relationship between multiple identities and within systems of repression. Intersectionality has a place in history, defining Black women experiencing as a 'double jeopardy' and a 'triple oppression'. These complex identities are the centre of social stratification, hierarchies, power, and privilege. The Combahee River Collective 213 (in Carastathis 2014: 305) states that 'the analytic distinction between, for instance, 'racial' oppression and 'gender' oppression distorts their simultaneous operation in the lives of people who experience both'. This analytical distinction lends itself to understanding the intersectional experiences of Black women academics. Black women frequently experience oppression, and this is an interrelated distinctiveness. The interconnectedness between hierarchies of power and social systems of oppression is a precursor to conceptualising intersectionality. An understanding of group identities of Black SA women in specific communities, i.e. academia is mandatory. Women's experiences of intersections between work and family are linked to their emotional and financial responsibilities. Nunez (2013: 40) maintains that,

Intersectionality has the potential as an analytical tool to transform HE into a social site that offers individuals, particularly those from historically marginalised backgrounds, more equitable chances for economic and social mobility, in a society that has historically been characterised by significant social inequality. They were already considering the role of multiple identities with relationship to various social contexts and interlocking systems of power, privilege, and oppression in shaping HE experiences and outcomes.

\section{Methodology}

The study adopted a qualitative approach with the use of open-ended ques- 
tions. The qualitative interviews took place with Black women employed in a permanent full-time capacity at all five locations of the University of KwaZulu-Natal (UKZN). The primary aim was twofold: a) understand the intersections experienced by Black women in the academy; b) and to understand their lived gender and race experiences accurately. The ten participants were selected via purposive sampling based on their race and gender profile from all five campuses. Securing participants was a challenging exercise; Black women academics were particularly cautious about sharing their lived experiences. All participants completed informed consent and were guaranteed anonymity (Ramnund 2019).

Interviews were recorded on an audio recorder, and were subsequently transcribed. All audio recordings were securely stored and will be destroyed after five years. The qualitative data analysis software, NVivo was used to determine pertinent themes that emerged. Challenges faced by South African Black women in academia are not dissimilar to global experiences. However, the South African results can be compared to global perspectives cautiously, given its unique higher education history. It was essential to understand the university policies and its employment equity plan. Human resources were not forthcoming with this information.

Approximately 62 Black women academics were initially invited to participate in this study. Those that declined reported time constraints citing high academic workloads. Similarly, approximately 25 Black women declined to speak about their lived experiences, openly indicated fear of victimisation by managers. This fear was particularly evident on both the Howard College and Westville Campus. While respondents understood that their anonymity was guaranteed, they declined meetings in their personal offices, and refused to engage telephonically and electronically. They alleged that their offices and telephone lines were under constant surveillance. The table below reflects ten Black women participants that voluntarily participated in the study.

\section{Table 8: Biographic details of participants (Pseudonyms)}

\begin{tabular}{|l|l|l|l|l|}
\hline $\begin{array}{c}\text { PARTICIPANTS } \\
\text { PSEUDONYM }\end{array}$ & \multicolumn{1}{|c|}{ CAMPUS } & $\begin{array}{c}\text { DESIG- } \\
\text { NATION }\end{array}$ & $\begin{array}{c}\text { HIGHEST } \\
\text { QUALIFI- } \\
\text { CATION }\end{array}$ & RACE \\
\hline Anita & Pietermaritzburg & Lecturer & Master's & Indian \\
\hline Beena & Pietermaritzburg & Lecturer & PhD & Indian \\
\hline
\end{tabular}


Gender and Race in the Trajectories of Black Women Academics

\begin{tabular}{|l|l|l|l|l|}
\hline Dudu & Howard College & Lecturer & Master's & African \\
\hline Geetha & Westville & Lecturer & Master's & Indian \\
\hline Hema & Medical School & $\begin{array}{l}\text { Head of } \\
\text { Department - } \\
\text { Professor }\end{array}$ & MBChB & Indian \\
\hline Indira & Medical School & $\begin{array}{l}\text { Academic } \\
\text { Leader - } \\
\text { Professor }\end{array}$ & MBChB & Indian \\
\hline Janikie & Medical School & Professor & MBChB & Indian \\
\hline Kamila & Edgewood & $\begin{array}{l}\text { Cluster } \\
\text { Leader - } \\
\text { Professor }\end{array}$ & PhD & Indian \\
\hline Laila & Edgewood & $\begin{array}{l}\text { Head of } \\
\text { Department }\end{array}$ & PhD & Indian \\
\hline Mpho & Edgewood & Lecturer & PhD & African \\
\hline
\end{tabular}

\section{Institutional Culture}

The existence of racially fractured institutional cultures at English, Afrikaans, HBUs and Technikons saw divergent practices, gender roles, and race identities forged within the post-apartheid academy. HE institutions began corporatizing in line with global trends. Academics were directed into a multiplicity of non-academic roles within a new institutional culture, tasked with budgets; efficiency effectiveness; human resource; administrative and performance management processes became the responsibility of academic departments. The Dean was replaced with an Executive Dean (Cloete et al. 2004); this (Higgins 2007) a result of the transformation in 2004. According to Mazibuko (2006: 108),

Mergers, like all change processes, can result in, (a) organised resistance formations attempting to guard the practices of the past fiercely; (b) loss of privileges that come with past practices; (c) attempts to maintain the culture of exclusion in all its forms such as the isolation of promising female scholars; and (d) passive mentoring and subtle non-transference of competencies and skills.

Badat (2010) contends that the history of inequality remains deeply rooted in current political and economic structures. Statistics from HE 
institutions in 1994 indicated that $83 \%$ of academics were White, and $69 \%$ of this sample was White males. The SA Black population accounts for $89 \%$, with $17 \%$ being Black academics. In 2006, statistics indicated $62 \%$ of academics were White, and $58 \%$ were White males. While Black academics accounted for $38 \%$ of the total academy, Black women accounted for $31 \%$ to $42 \%$ of this group (Education Statistics in SA 2008). Tierney (1988: 30) asserts that,

Institutions certainly are influenced by powerful, external factors such as demographic, economic, and political conditions, yet they are also shaped by strong forces that emanate from within. This internal dynamic has its roots in the history of the organisation. It derives its force from the values, processes, and goals held by those most intimately involved in the organisation's workings.

When inferences to culture, traditions, customs, and values underpin decisions, the question of inclusivity or exclusivity towards women must be advanced. According to Vincent (2013),

Institutional stories are used to induct people into institutional membership. Moreover, part of this process of induction has to do with individuals learning to "shape their stories to harmonise with the events and values of the main institutional values.

Academic institutions transformation is separated into three key periods, 1) pre-1994, 2) 1994-2004, and 3) post-2004. This makes it difficult for academics to share familiar institutional stories; their narratives are determined by their identified period in HE. The UKZN transformation charter subscribes to encouraging transformation plans; however, experiences of research participants provided no evidence of the charters enforcement. The objectives of the charter outline that the university should be free of discrimination on ethnicity, race, gender, class, nationality, religion, sexual orientation and disability, and it must reflect race and gender representation in its management structures, personnel profile, and student population (Ramnund 2019). The inconsistency with compliance with the employment equity policy of UKZN was central to the findings. While specific schools published their progress with compliance, the UKZN human resource sector has failed to provide a comprehensive public report. 
The university's online 2016 annual report provided a 2015 employment equity profile. The $2012-2015$ profile confirmed academic staff at UKZN constituted 28\% African staff in 2015 from a recorded 20\% in 2012. This was an improvement from the $16 \%$ African academics in 2004. There were $34 \%$ White academic staff in 2012, which decreased to $28 \%$ in 2015 , while Indian and Coloured academic staff remained relatively unchanged at $30 \%$ and $2 \%$, respectively. Discrepancies with gender reporting statistics were noted in the same report from UKZN. The UKZN 2016 online annual report indicates that women constituted 55\% of academic staff in 2016, compared to $55.72 \%$ in 2015. The June 2015 Parliamentary Portfolio Committee on Higher Education and Training reports that women constituted $48 \%$ of all academic staff, an improvement from $41 \%$ in 2004 . UKZN reports further indicate that Indian, White and foreign national men and women academics were overrepresented in the employment equity profile of 2016. The number of academic staff awarded $\mathrm{PhDs}$ increased by $3 \%$ to a total of $50 \%$. However, African men and women were still underrepresented at academics ranks of Full Professor $(5.17 \%)$ and Associate Professor (15\%). The number of African women at Full Professor level increased from $0.85 \%$ in 2015 to $1.72 \%$ in 2016, and African women Associate Professors rose from $7.14 \%$ in 2015 to $8.57 \%$ in 2016.

These statistics were consistent with responses to institutional culture. Participants Anita, Beena, Dudu, Geetha, Hema, Indira, Janikie, Kamila, Laila, and Mpho confirmed that the current institutional culture was not a result of the merger. The university has undergone several change processes postmerger, which has continually transformed institutional culture. The initial challenges experienced by Edgewood and Westville academics shared that they 'did not feel like they were a part of the former University of Natal network'. They confirmed a focus on policies related to their department. Laila stated: 'The bigger picture of the UKZN institutional culture did not affect us immediately. Our school (Edgewood) had subcultures which worked and we continued to use it for as long as we could'. They maintained the status quo of the historically English University of Natal. Kamila stated,

The first transition was from being Edgewood College to becoming a part of the University of Kwa-Zulu Natal. We were still familiarising ourselves with these changes, and we were then part of a merged UKZN. We operated in the ways which worked for us in the original Edgewood School. 
Other consistent narratives referred to current institutional culture perception. All participants reported dissatisfaction with bureaucratic and institutional management, which included the new performance appraisal system. According to Hema,

Previous institutional culture was seamless. The current culture is too corporate. Cognisance is not taken of specific fields or departments. The same structure and paperwork apply to all. The promotion criterion is impossible for clinicians. A recommendation is being sent to the executive level to adapt promotion criteria for clinicians specifically.

Other instruments adopted with the new institutional culture came from Kamila: 'new promotions policy, new performance management system, workload policy all come straight from the top. It is very autocratic, with no consultation or communication. The culture is very closed'.

The former University of Natal was perceived to have a conducive culture advantageous to a successful academic career. Academics narrated experiences of 'the good old days', creating a resistance from departments to embrace new institutional culture. Academics employed at the former University of Natal alleged that work-family life balance was less achievable with increased research outputs. Mpho was dissatisfied that the university was 'being run like a company'. She verified that institutional culture gave credence only to UKZN trained academics, academics who obtained a degree outside are categorised UKZN as 'outsiders'. Indira said that 'with the new UKZN and the new conditions of service, it placed additional pressure on medical school academics, which caused them to leave for private practice or to emigrate for job opportunities'. Institutional culture prompted the departure of senior experienced academics and clinicians from the Medical School, resulting in a significant knowledge gap. Anita's experience on the new institutional culture was also negative. 'It has increased academic workload in terms of teaching hours and research outputs'. The new conditions of service disadvantages staff, according to her, in terms of benefits. 'Different campuses have different institutional cultures'. She has to work with the Westville Campus who 'are part of a very relaxed environment and culture, and do not care to meet deadlines'. This new culture impacted negatively on her key performance areas. Janikie confirmed that she did not feel an immense 
difference in the institutional culture.

However, there were huge drives to change the status quo. Structures shrunk. The administrative staff was shared. There were problems with efficiency because things were not thought through. At the top decisions are made, but it does not always work in practice.

The lack of consultation made change difficult. Geetha specified that there was a difference in culture pre-merger and post-merger. 'Pre-merger, they interacted with more departments. The environment was more personalised and warmer'. Post-merger, her 'school was the one with the least horror stories'.

New criteria used to appoint academics has resulted in the exclusion of qualified academics, lending to their racial classification. Vacancies became impossible to fill with the prescribed criterion; the implications were increased workloads. Institutional culture is compelled to recognise the guidelines offered in the employment equity policy, in line with both race and gender imperatives. The implementation needs to be aligned to a plan with clear goals, driven by an executive process systematically. The dissatisfaction experienced by Hema, Laila, Indira, and Janikie with the implementation of equity policies is particularly evident with the distortion of recruitment and selection being 'unfairly' applied, indicating that academics were not 'recruited based on skill but rather to fill a race quota. The directive concerning recruitment in vacant positions was to appoint African women only'.

This directive focusing on Black African women impacted the morale of other Black women academics in the department working toward promotion. Hema stated,

The implementation of the Employment Equity policy to appoint only Black African women has been difficult in my department. There is a lack of Black women in the specialised field and hiring junior candidates to fill senior portfolios without a proper skilling program in place puts pressure on the entire team.

The morale was affected as unfilled academic posts impacted on academic workloads. Laila was happy with the university's commitment to employment equity with reservation as she noted, 'Black lecturers are 
recruited, but there is no upward mobility'. It was really essential for a structured development and mentoring process to be in place before this was ever considered. According to Indira, the employment equity process is severely flawed. Although she supports equity, she believes that the process is not regulated and correctly executed at medical school. 'Black (African) women are being appointed based on race and not merit. A natural development did not occur with Black appointments'.

At managerial levels, their subordinates were unhappy, and the incumbent could not deal with difficult students. They did not want to accept help because they 'know everything'. The participant, Indira confirmed that she was in support of transformation. However, planned, structured transformation was critical for succession planning to ensure that the incumbent did not fail. To appoint academics to fulfil quotas laid the foundation for impending disaster. 'The rules of promotion were overlooked to accommodate Black (African) women. Appointments were not made based on the criteria, but race alone'. According to Janikie, the merger came with an,

Anti-Indian sentiment in Medical School, as Medical School was seen previously as an Indian stronghold. The atmosphere caused many good academics to leave. Black African staff that fail to meet the minimum academic requirements are employed. Departments are losing their accreditation with the Health Professional Council of South Africa (HPCSA) because of the lack of experience of the Heads.

The UKZN employment equity policy defines women as a designated $^{14}$ group and addresses areas of recruitment; development, succession planning, and capacity building in a generic manner; it does not include specific targets aimed at gender development and career advancement. It has

14 'Designated groups' include all black people (i.e. Africans, Coloureds, and Indians). Citizens of the Republic of South Africa by birth, descent and naturalization before the 27 April 1994 of the Constitution of the Republic of South Africa Act of 1993 include women and people with disabilities. 'Citizens of South Africa' include individuals previously excluded by the apartheid policy that had been in place before the commencement date of the Constitution of the Republic of South Africa Act of 1993 and had the right to acquire citizenship by naturalization before that date. 
failed to include a transparent operationally viable implementation plan, which is the impetus for the challenges experienced by academics at UKZN. The knowledge secured from interviews offer effective alternative solutions for long-term success by challenging incongruous academic appointments to fulfil gender quotas. The legislation cautions against this practice, citing disadvantages if incumbents receive inadequate support and mentorship; the implementation at UKZN excluded all designated groups in favour of Black African women.

\section{The Old Boys' Network}

A crusade from the traditional old boys' network towards a balanced and more inclusive culture seems irredeemable. HE practices indicate increased barriers to the recruitment and advancement of women in the academy. The barriers are evident in HE historical institutional culture focused on a pedagogically ratified old boys' network.

A management role in HE for women often means that the female manager has to deal with highly educated individuals in her department daily. She further has to deal with and overcome problems of sex-role stereotyping, culture (the old boys' traditions), issues around her appearance and dress; and leadership style (Welch 1990: 168).

Gender socialization plays a significant role in how women are located in the academy, challenges with advancement are related to gender, and male power roles are evident. Welch (1990: 169) refers,

The female manager must be able to break away from the popular public image of the mothering nurturing woman whose duty is to stay at home and tend the family unless she is ridden with guilt for all times. The working woman must learn to reign in the traits that are stereotypically labelled 'female' since this behaviour is what men (sic) have learned to devalue and deride.

Participants confirm that the appointment of women leaders in HE (Medical School specifically) is in line with compliance to affirmative action, 
insinuating that their appointment is guided by national imperatives versus competence. Similarly, the view of an older woman who survived the HE patriarchal culture. Women are forced to expand their career prominence by 'accepting' the implicit rules and discernments (Welch 1990). Women endure predominantly feminised faculties, administrative departments, student affairs, libraries, commonly locating themselves in social science faculties, vs 'maledominated' faculties of science and engineering (Kuk \& Donovan 2003; Bailey \& Mouton 2004).

Notwithstanding their negligible advancement to management positions, the science faculty remain a firm glass ceiling for women. 'It is estimated that, on average, only $30 \%$ of science roles throughout the world are held by women' (Butler-Adam 2015: 45). The Academy of Science of SA is led by a woman; however, she is one of only three women that constitute the 13member scientific council. The University of Cape Town appointed its first woman Dean of Engineering, in its 186-yearlong history. Her appointment makes her one of only two women to hold this position in South Africa. ButlerAdams (2015) blames education and socialisation for the slow entry of women into the science faculty. 'There is a lingering tradition in some schools of encouraging boys to study physical science and girls to focus on biology and becoming teachers' (Butler-Adam 2015: 46). The public library of science found that women authors are often compelled to work with male industry leaders if they want to publish. Greene (1990: 89) advocates that tokenism masks racism and sexism. By welcoming exclusively Black African women into $\mathrm{HE}$, opportunities for all other competent women into the academy are disordered. Greene (1990) finds the appointment of Black women professors in small numbers demonstrates the Universities' commitment to parity while exemplifying the complete mediocrity of Black women as a group. West (2006) claims that male board members find that bureaucratic mechanisms impede salary increments, maternity paternity, and family responsibility leave when propositioned when considering policy, male board members gatekeeping underlines existing gender prejudices in academia. Ramsay (2001: 14) states,

Senior university women can no longer be overlooked at the individual or collective level, achieving audibility, visibility, and credibility for women across the sector - in their own eyes and in those of the 'status judges' who are so influential in determining who 
is nominated to career-enhancing opportunities in the sector.

Ramsay (2001) features global equity gaps in HE within the context of change and competition. He establishes a need for developmental programs to enhance skills and competencies mandatory for advancing women into academic leadership. In 2004, SA statistics identified the presence of gender incongruences at distinctive academic levels. Former Technikons' disparities appear less noticeable with $5 \%$ women and $10 \%$ of men located at the level of junior lecturer and $22 \%$ of women at the same level. This in contrast to $28 \%$ of men at senior lecturer level. Comparatively, at universities, women overshadow men at junior and lecturer levels. The Associate Professor level sees $7 \%$ of women, compared to $13 \%$ of men, and at Professor level sees $7 \%$ of women as opposed to $26 \%$ men (Bailey \& Mouton 2004).

Substantiation of the glass ceiling ${ }^{15}$ implies the overarching existence of an old boys' network within the South African HE landscape. The responses to the old boys' network were strong and pervasive, confirming that the network is still prevalent. According to Kamila, 'if the old boys' network continues to exist, I choose to ignore their existence and focus on my productivity', while Laila confirmed,

The network is firmly established, frequent reference to the 'old days ...' where strong views of masculinity predominated. White males are frequently exemplified as 'experts and authority'. The old boys' network ensured unambiguous exclusionary standards by which men live and work. Change is occurring slowly.

Hema: 'The old boys' network is made up of prominent white male academics that control the UKZN hierarchy'. Mpho was very vocal about gender prejudice. She was a published researcher with a $\mathrm{PhD}$ but had to 'fight' for a permanent position. She was appointed as a lecturer when she met all the requirements of a senior lecturer. She commented that 'the system undermines

${ }^{15}$ The ability to see, but not reach top management positions due to the patterns of subtle discrimination that exists in all areas of work. The United States Congress passed the Glass Ceiling Act as Title ii in the Civil Rights Act of 1991 in an attempt to eliminate artificial barriers to advancement (Baron 2000: 698). 
race, the male dean had his favoured candidates', and she was disadvantaged because she was seen as a 'UCT girl and not a UKZN girl'. The use of the label girl signals the systemic gender incongruences at UKZN. Her male colleagues questioned her qualifications and her publication record. She used the term 'academic jealousy' to describe this. She also believes that 'Black challenges' are not recognised.

It takes a Black woman longer to complete her $\mathrm{PhD}$ due to cultural pledges and family integration. As an educated employed Black woman with a 'good job' she is responsible for mentoring all family and community children, she also has an added responsibility to children admitted to her university. She is expected to accommodate them in her home, the responsibility of family commitment features strongly within the African culture. This is not disregarded by the old boys' network. Indira's challenge is influenced by the old boys' network. Men would often say, 'she doesn't know how to do that'. She recollected two relatable milestones that were marred by how her male colleagues and subordinates treated her. When appointed head of department, academics attempted to 'sabotage my department', and when promoted to Associate Professor, her white male colleagues who failed to acknowledge her experience ridiculed her instead of applauding her success. Anita established existing gender biases with no acknowledgement of work-life balance, domestic and childcare. While she has the responsibility of a sizeable first-year group, her male colleagues are allocated favourable student supervision to satisfy prescribed hours. Supervision of masters and doctoral students present opportunities for publication, with her current supervision allocation of two honours students, she is disadvantaged. According to Anita, men and women academics are treated differently, males are sustained and afforded added opportunities to advance. Women arrive at their second unpaid jobs at home to provide dinner, childcare leaving them no time for research outputs. Laila experienced a similar episode where senior male academics would take parts of her research without permission and publish it as their own; this after she would ask for guidance on her research. Male academics societal location facilitates their roles into senior positions expeditiously compared to the societal location of women which obstructs their access to senior academic positions.

\section{Role Overload}

The balance of work and familial roles is problematic in a multitude of ways, 
Greenhaus, Collins and Shaw (2003) note individuals inevitably organise their roles in a hierarchy of prominence. Marks and MacDermid (1996) propose that individuals should demonstrate constructive commitments to numerous life roles, and hold a balanced orientation to multiple roles. Swanson and Johnston (2003) observe that balancing family responsibilities, for women with children under the age of 10 affected their research productivity negatively. The same study asserted that women are increasingly discouraged and discontented, irrespective of academic level. Dominant expressions of dissatisfaction stem from women's societal burden to 'manage the institutional housekeeping - i.e. committee work, student recruitment, departmental social events' (Swanson et al. 2003: 3). Ward and Wolf-Wendel (2003) highlight that although academic freedom and flexibility attract women to academia, they remain frustrated with increasing workloads and work life balance. Bird, Litt and Wang (2004: 195) cite institutional housekeeping as,

Represents the invisible and supportive labour of women to improve women's situation within the institution. Much like unpaid domestic housekeeping typically performed by women in family units, institutional housekeeping is usually performed without resources or recognition.

Institutional housework forced on women reduces research outputs adversely affecting advancement opportunities.

Bird et al. (2004) propose that women at HE institutions must be accountable for producing research and intelligences on gender impartiality to construct models that support and advance women in the academy. While HE has policies and models that guide academic workload allocation, the implementation is flawed in the disproportional allotment of institutional housekeeping to women. There are numerous gaps in the apportionment of this type of work to women. 'Many models for allocating work exclude research from their calculations exacerbates this. Additionally, this feeds off the expectations that research work ought to be conducted after hours at home' (Barrett \& Barrett 2011: 141).

The distribution method and gendered structural allocation of academic workloads directly impact on women proliferating obstructions for advancement, while the scarcity of mentorship impedes promotion preventing entry into management. Women concur that academic trajectory advances and 
decision-making ability ensue simultaneously, resulting in sureness of participation at a policy level. 'More female academic staff have a fragmented career, and this is probably connected with their lower expectations and aspirations in both management and academic roles' (Barrett \& Barrett 2013: 43). Women uninterruptedly encounter a crisis of conscience; overloaded with teaching, administration, and institutional housekeeping, leaves no time for research. Advancement of women into management necessitates effective ways to transcend challenges. The supreme achievement of increased prolific publications and timeous graduation of masters and doctoral candidates remain the foremost priority for women in academia. Transformed institutional culture is responsible for increased workloads. This occurs via the streamlining and restructuring of departments, which left the administrative burden to academics, while the promotion policy criterion averted any possibility of work life balance. The excessive mandates of teaching, research and supervision were confirmed by Anita, who indicated that she bore a tremendous burden of the work which should be shared with her colleagues on another campus. She was diligent with deadlines; she was compelled to accept excessive workloads. The lack of commitment from colleagues compromises the credibility of the academic programme. Anita's annual teaching workload exceeds prescribed senate norms; yet she is still expected to assist when colleagues are on maternity leave, sabbatical and sick leave. Efforts toward academic promotion are futile in the HE institutional culture.

Janikie stated that UKZN had undergone structural transformations, reducing administrative staff significantly. The prescriptive increased workload 'teaching undergrads, supervising postgraduates, running clinics in public hospitals as well as the day to day activities'. A dedicated administrator to support her became a shared administrator, centrally located and shared between departments. She indicated that academics were required to utilise personal funding to secure assistance. Geetha confirmed post-merger saw a significant change in administrative roles and new academic requirements placed mounting pressure on academics, prompting the departure of numerous reputable academics. The new key performance areas post-merger demanded unreasonable teaching, research, supervision and administration. Geetha confirmed that she was not actively involved in research, nor was she working on any publications, largely because she had not completed her $\mathrm{PhD}$. She made a conscious decision to focus on her child who was experiencing health challenges, while she executed her work professionally and timeously. She 
gave little though to unreasonable demands imposed on academics. The increased teaching workloads is linked to unfilled academic vacancies, and Geetha is located in a scarce skill discipline. Mpho conceptualises that role overload is more complicated for Black (African) people because they have 'Black challenges'. She qualified this with,

English is difficult for many black people because it may not be a first language, which makes task completion more complex and may take longer. Family and cultural bonds are deep-rooted within the black community. An academic may be the only person in the family (extended family) or even village to go to university and become a lecturer. Academic demands may be difficult, as we have to look after cousins and nieces and nephews, not only financially but also encourage and motivate them; this is expected.

Dudu verbalized that role overload is a bona fide problem; she was expected to manage her $\mathrm{PhD}$ research, teaching, supervision, and publications. It was difficult to do everything at work because students do not respect consultation hours, so she is forced to complete work at home. She habitually works early mornings, usually three hours before her children wake up, her familial responsibilities are unfulfilled, while she uses her time to complete academic tasks after hours. Her line managers are exceptionally supportive and try to offer support by engaging contract staff; however, university policies hamper any support. Beena was visibly frustrated with her work overload in what she explained as 'dirty politics'. She confirmed that once a lecturer obtained his/her $\mathrm{PhD}$, they were 'loaded with teaching large classes, work on weekends was essential to catch up on the administration leaving no time or space for research', despite research, publication and new knowledge creation outlined as the principal role of academics worldwide. Collectively all women participants were aggrieved by the incongruous role overload assessed against male colleagues' non-exacting teaching load. Men and women academics on the same level with equivalent experience effortlessly secured favourable workloads. Male academics commanded the allocation of postgraduate students to facilitate publications. Bailey and Mouton (2004) indicate that women academic research outputs were expressly lower compared to male research outputs between the years 1990 and 2001. Publications result in productivity units, which translate into funding resources made available to the 
academic in a separate university-regulated research account. In 2001, women received merely $21 \%$ of all research grants and only $42.5 \%$ master's and doctoral scholarships, confirming that men earned the greater share of grants (Bailey \& Mouton 2004).

... women are equally committed to their profession as men, but have limits on their time due to a myriad of factors: obstacles inherent in $\mathrm{HE}$ jobs and disinterest in a tenure track position because of work and family life balance and academic expectations; women have greater teaching loads than men and less access to resources necessary for research; and women's commitment to teaching and service minimises their time for research (Bingham \& Nix 2010: 5).

Transforming institutional culture resulted in an increasing number of students at HE institutions, contributing to the exponential growth of academic teaching workloads. Women carry the highest teaching workloads and endure subjugation by men in academia. The cognisance of patriarchal practices remains firmly rooted in SA; students are likely to approach women academics with personal issues and general academic queries. This impacts the time management of women academics who have reported incessant requests for validation of qualifications and publications by students. Narratives exposed male academics as unambiguously harsh against women, debasing their role as academics. In an actual case, a male mentor shredded an idea proposed by a woman academic in full view; he acted in an aggressive and intimidating manner, resulting in emotional trauma for the women. Perfunctory appointments established by the old boys' network employ 'favoured candidates' of decision-makers in authority. Complaining academics that demonstrate behaviour characteristic of 'a bootlicker' are offered concessions for sabbaticals, funding and teaching. The compliance by 'bootlickers' makes them suitable candidates for promotion to positions that reinforce role overload and cement the old boys' network. The characteristics of the bootlicker, the successful and favoured woman, include acting on instruction with no protestation, perform and executes tasks by sacrificing family and personal time. These perfunctory appointments guarantee success for women by surreptitiously buttressing the old boys' network, which endeavours to 'punish' outspoken women who subscribe to the equitable allocation of teaching, supervision and research responsibilities. 


\section{Academic Bullying}

Bullying appears to be a common occurrence in academia. According to Keashly and Neuman (2010), organisational culture and institutional climate are key determinants of bullying. Cassell (2011: 34) notes Von Bergen's (2006) view of bullying as,

Harassment that inflicts a hostile work environment upon an employee by a co-worker, typically through a combination of repeated, inappropriate, and unwelcome verbal, nonverbal, and or low-level physical behaviours that a reasonable person would find threatening, intimidating, harassing, humiliating, degrading, or offensive.

The women in this study are primarily victims of this behaviour, in spite of their different positions in academia. The severe consequences of bullying adds to the significant professional challenges. The adverse impact of bullying includes poor job performance, higher employee turnover, powerlessness, depression, demoralisation, and a negative impact on health (McKay et al. 2008). Mobbing is identified as a form of bullying and is demonstrated by a collection of a few people who intimidate, humiliate, and exclude a particular member of the staff. This is frequently accomplished via e-mail or direct altercation and is targeted at maliciously forcing a particular worker out (DeFalco \& Crabb 2005). Women constitute victims of mobbing primarily when they are located in a male-regulated faculty that subscribes to inequity. Institutional inattentiveness to the work environment compounds gender challenges, the need to reinforce and adhere to institutional policies on workplace bullying is mandatory (Ramnund-Mansingh \& Seedat-Khan 2020). Without the engagement of human resources and decisive leadership, bullying and vulnerability to workplace abuse will remain a challenge for women in HE.

Two broad causes of abusive behaviour in the workplace have been identified, 1) personal (narcissism, fear, outcome uncertainty, power motives, object beliefs, negative life themes and lack of selfregulation); and 2) situational (alienation, non-supportive family, negative role models, life stressors, competitive pressures, exposure to negative superiors or peer groups, and financial need of the individual (Cassell 2011: 38). 
In the United States, candidates on a tenure track position are guaranteed job security, a permanent academic position, and a structured plan for promotion to different stages until the level of Full Professor. Tenured candidates are likely to be greater targets for bullying while the converse also holds when the tenured group grips enough power to be bullies (Lester 2013). Curtis (2011) indicates that between 1976 and 2009, women have maintained $34 \%$ to $38 \%$ of full-time tenure positions in faculties while men maintained between $48 \%$ to $58 \%$. Studies in the United Kingdom found definite empirical relationships with gender and bullying; women were more likely to report incidences of bullying and were more likely targets than men. In the same study by Simpson and Cohen (2004, cited in Taylor \& Anderson 2012), traits of bullying behaviour, identified by women, were justified by men as acceptable management styles.

The engagement with respondents recorded, specific and repeated references to the unequal treatment, exploitation, unprocedural academic appointments, glaring sexism, and disrespectful treatment of women academics. There is a sufficient body of evidence to establish a compelling link between the function of the old boys' network and occurrences of academic bullying experienced by women. Women academics frequent experiences of protracted bullying inflicted by the force of male colleagues. Anita confirmed that men received more postgraduate students to meet their production units. Hema cited an example of her research mentor, indicating 'the power dynamic is too strong. Instead of supporting the woman mentee, he breaks her down emotionally and devalues her. Eventually, he submitted her research papers as his own and not as a collaborated effort'. Indira confirmed that academic bullying takes place at differing magnitudes and different contexts, when she was promoted to associate professor, her White male colleagues chose to ridicule her. She expounded that male academics are individualistic and selfcentred; if they are dissatisfied with a woman in a leadership role, they will sabotage all activities that impact the overall performance of her leadership 'knowing that it would impact the overall performance of that department'. Kamila confirmed that 'there was a lack of support for women. Men trivialised women academics work by constantly putting them down'. Laila stated that 'women are not emotionally strong enough to take on the fight and they are not supported in the fight by other women academics'. Laila further cited the example of a research mentor who would 'break the women down emotionally by shouting, being rude and arrogant. There is little or no chance of research 
success in a relationship of this nature'. Mpho responded with emotional intensity regarding her experiences of academic bullying; male colleagues undermined her qualifications and research outputs. Although she was qualified to become a senior lecturer, she was appointed as a lecturer with an entry-level salary. She believed this was inconsistent with levels of male colleagues who were less qualified and had fewer research outputs. However, she was not one of the 'favoured academics' for the position of department head. Being a part of the 'favoured academics' guarantees research, teaching, funding and supervision support. The 'favoured academics' include men and women 'bootlickers', and Indira identified them as the main perpetrators of academic bullying. Women can make a choice how to exercise their power. When Indira registered her $\mathrm{PhD}$, she turned to women in her department who had supported male academics research endeavours. These women impeded her efforts and rejected her pleas for lab work support required to conclude her $\mathrm{PhD}$. Consequences of academic bullying include stress (McKay et al. 2008), and the failure to recognise women academics' experiences of bullying, the aggression of male academics towards them, and the absence of support from women colleagues cause high levels of stress. Stress symptoms can manifest in physical ailments; Anita indicated that her stress levels were so high that she found herself in hospital on several occasions due to stress. Mpho confirmed that her high levels of stress contributed to physical manifestations such as diabetes, high blood pressure and ulcers.

\section{Conclusions and Recommendations}

This paper provided a detailed theoretical framework that facilitated an indepth understanding of the intersections of race and gender on 10 Black women academics at UKZN. The research was contextualised with a detailed scholarship review on HE. Apartheid legislation was recognised for its harsh impact on $\mathrm{HE}$ and its role in racially segregated institutions. The complexities of race, gender and class have provided a conduit to intersections of culture, patriarchy, socialisation and identity within the context of this study. Having successfully contextualised HE institutions in three stages - pre-apartheid, a post-society and a transformed HE institution - this commemorates the foundation for much-needed interrogation in academia. The scholarship gives credence to diverging theoretical perspectives within the context of HE. Citations of generic theories and research typifying erstwhile fields of expertise 
were limited and identified as areas for significant research. The intersections evident include race, gender, class, socialisation, patriarchy and culture. The four key themes that emerged indicate that social constructionism and intersectionality shape the realities of Black women academics, regardless of the prevailing equality.

The institutional culture moves toward corporatized outputs, and revised and realigned performance review systems are inconsistent with traditional academic roles. The absence of a consultative process fails to consider the impact on the whole institution. The old boys' network continues to exist with an extensive and diverse group of male academics joining the network. Evidence that the old boy's network plays a significant role in facilitating circumstances of academic bullying, empirical evidence corroborates that men monopolise and have successfully retained their position on top of the institutional hierarchy. They are positioned to make important decisions that influence institutional policy, positions of privilege held by male academics regulate academic appointments and promotions.

HE institutions ought to be compelled to provide guidelines for promoting equity, growth and opportunities for all Black women in academia, in line with race and gender national imperatives. The current interpretation of the policy adopted has moved to the exclusive appointment of Black African women, excluding all other women. This decision gave no consideration to the experience and qualifications required to fulfil the requisite responsibilities in academia. Appointments are both perfunctory and based on networks and relationships developed with compliant candidate bootlickers who ultimately reinforce and provide support to the old boy's network. While challenges relating to institutional culture, old boys' network, role overload and academic bullying are not unique to South Africa, the challenges experienced are further compounded by intersections of race, gender and class.

The most significant failure of the HE Act 101 of 1997 was the absence of a code of good practice to advocate the advancement of all Black women in the academic world. This is the fundamental basis of the slow pace of transformation for women in the SA academy. If HE institutions in SA fail to urgently prioritise and address the key challenges related to academic appointments, teaching workloads, labour practice and gender inequities, the second exodus of valuable, skilled academic staff is inevitable. The establishment of both private and international ivy league universities in South Africa is likely to attract experienced academics, leaving public universities in a weakened 
position. The inability of South African public universities to compete with large international universities is becoming increasingly inevitable; if HE stakeholders are to mitigate the risk of institutional collapse, it is critical to begin with a strategic intervention directed at a national level, beginning with a code of good practice that protects the sanctity of South African universities and preserve the function of scholarship in academic excellence.

\section{References}

Aulette, J.R., J. Wittner \& K. Blakely 2009. Gendered Worlds. New York: Oxford University Press.

Badat, S. 2010. The Challenges of Transformation in Higher Education and Training Institutions in South Africa. Development Bank of South Africa. Bailey, T. \& J. Mouton 2004. Synthesis Report - Women's Participation in Science, Engineering, and Technology. Supported by the Department of Science and Technology and National Advisory Council on Innovation. Pretoria.

Bantu Education Act (No 47, of 1953). Online available at:

https://www.sahistory.org.za/sites/default/files/archivefiles2/leg19531009.028.020.047.pdf

Baron, D.P. 2000. Business and its Environment. New Jersey: Prentice-Hall. Barret, L. \& P. Barret 2011. Women and Academic Workloads: Career Slow Lane or Cul-de-Sac? Higher Education 61: 141 - 155. https://doi.org/10.1007/s10734-010-9329-3

Basic Conditions of Employment Act (No 75 of 1997). Online available at: https://www.gov.za/documents/basic-conditions-employmentact\#: :text=The\%20Basic\%20Conditions\%20of\%20Employment,basic $\% 20$ conditions $\% 20$ of $\% 20$ employment $\% 3 \mathrm{~B} \% 20$ and

Berger, P.L. \& T. Luckmann 1979. The Social Construction of Reality: A Treatise in the Sociology of Knowledge. New York: Anchor Books.

Bingham, T. \& S.J. Nix 2010. Women Faculty in Higher Education: A Case Study on Gender Bias. Forum on Public Policy for A\&M University. West Texas.

Bird, S., J. Litt \& Y. Wang 2004. Creating Status of Women Reports:

Institutional Housekeeping as 'Women's Work'. NWSA Journal 16: 194 - 206. https://doi.org/10.2979/NWS.2004.16.1.194 
Boddy-Evans, A. 2020. School Enrolment in Apartheid Era South Africa. https://www.thoughtco.com/school-enrollment-in-apartheid-southafrica-43437

Burr, V. 2007. Social Constructionism. New York: Routledge.

Butler-Adam, J. 2015. Africa has a Long Way to Go to Get more Women into the Sciences. Watt Now - The Official Publication of the South African Institute of Electrical Engineers August: 44 - 47.

Carastathis, A. 2014. The Concept of Intersectionality in Feminist Theory. Philosophy Compass 9/5: $304-314$.

https://doi.org/10.1111/phc3.12129

Cassell, M.A. 2011. Bullying in Academe: Prevalent, Significant, and Incessant. Contemporary Issues in Education Research 4: 33 - 44.

https://doi.org/10.19030/cier.v4i5.4236

Cloete, N., P. Maassen, R. Fehnel, T. Moja, H. Perold \& T. Gibbon 2004. Transformation in Higher Education, Global Pressures and Local Realities in South Africa. Netherlands: Kluwer Academic Publishers.

Coloured Persons Education Act 47 of 1963. Online available at:

https://www.gov.za/documents/coloured-persons-education-act-24-may1963-0000

Curtis, J.W. 2004. Balancing Work and Family for Faculty: Why it's Important. Academe 90,6: 21 - 23. https://doi.org/10.2307/40252701

DeFalco, B. \& P. Crabb 2005. Academia Workplace Bullying: An Overview. Hazelton: Pennsylvania State University.

Education Statistics in SA 2008. Department of Education.

http://www.dhet.gov.za/DHET\%20Statistics\%20Publication/DoE\%20St ats\%20at\%20a\%20Glance\%202008.pdf

Employment Equity Legislation No. 55 of 1998. Online available at: https://www.gov.za/documents/employment-equity-act

Extension of University Education Act (No 45, of 1959). Online available at: https://omalley.nelsonmandela.org/omalley/index.php/site/q/031v01538/ 04lv01828/05lv01829/06lv01898.htm

Greene, L.S. 1990. Tokens, Role Models, and Pedagogical Politics: Lamentations of an African American Female Law Professor. Berkeley Women's Law Journal 6: 81.

Greenhaus, J.H., K.M. Collins \& J.D. Shaw 2003. The Relation between Work - Family Balance and Quality of Life. Journal of Vocational Behaviour v63: 510-531. https://doi.org/10.1016/S0001-8791(02)00042-8 
Higgins, J. 2007. Institutional Culture as Keyword. In Review of Higher Education of South Africa. Pretoria: The Council of Higher Education. Higher Education Act (No of 101 1997). Online available at:

https://www.gov.za/sites/default/files/gcis_document/201409/a101-

97.pdf; https://doi.org/10.1002/he. 9810

Indians Education Act, (No 61 of 1965). Online available at:

https://www.gov.za/documents/indians-education-act-26-may-1965$\underline{0000}$

Kanter, R.M. 1977. Men and Women of the Corporation. New York: Basic Books.

Keashly, L. \& J.H. Neuman 2010. Faculty Experiences with Bullying in Higher Education - Causes, Consequences and Management. Administrative Theory and Praxis v32: 48 - 70. https://doi.org/10.2753/ATP10841806320103

Kossek, E.E. \& S.J. Lambert 2005. Work and Life Integration. New Jersey:

Lawrence Erlbaum Associates. https://doi.org/10.4324/9781410611529

Kuk, L. \& J. Donovan 2004. Women in Higher Education Revisited: Intergenerational Conversations. Journal of Student Affairs 13: 1-10.

Labour Relations Act (No 66 of 1995). Online available at:

https://www.gov.za/documents/labour-relations-act

Lester, J. 2013. Workplace Bullying in Higher Education. New York: Routledge. https://doi.org/10.4324/9780203122938

Lorber, J. 1994. The Paradoxes of Gender. London: University of Yale Press. Marks, S.R. \& S.M. MacDermid 1996. Multiple Roles and the Self: A Theory of Role Balance. Journal of Marriage and the Family 58: 417 - 432. https://doi.org/10.2307/353506

Mazibuko, F. 2006. Women in Academic Leadership in South Africa: Conventional Executives or Agents of Empowerment? Alternation 13,1: 106 - 123. http://alternation.ukzn.ac.za/Files/docs/13.1/07\%20Maz.pdf

McKay, R., D.H. Arnold, J. Fratzl \& R. Thomas 2008. Workplace Bullying in Academia: A Canadian Study. Employee Responsibility and Rights Journal 20: 77 - 100. https://doi.org/10.1007/s10672-008-9073-3

Moutlana, I. 2001. Surviving the Boardroom Dance Institutions - The Land of Steady Habits. Presented at the conference: Forum for African Women Educationalists South Africa (FAWESA).

Nash, J.C. 2008. Rethinking Intersectionality. Feminist Review 89: 1 - 15. https://doi.org/10.1057/fr.2008.4 
Noble, V. 2018. A School of Struggle: Durban's Medical School and the Education of Black Doctors in South Africa. Durban: University of KwaZulu Natal Press.

Nunez, A.-M. 2013. Advancing an Intersectionality Framework in Higher Education: Power and Latino Postsecondary Opportunity. Higher Education: Handbook of Theory and Research 29: 33 - 92. https://doi.org/10.1007/978-94-017-8005-6_2

Ocampo, M.L. 2004. A Brief History of Educational Inequality from Apartheid to the Present.

https://web.stanford.edu/ jbaugh/saw/Lizet_Education_Inequity.html

Poloski, N. 2001. Basic Requirements for the Successful Implementation of the Feminine Leadership Style in Croatian Enterprises. HR Management 6,1: $119-131$.

Potgieter, C. 2002. Black Academics on the Move. Centre for Higher Education Transformation (CHET). Pretoria.

Ramnund, A. 2019. Exploring the Link between Institutional Culture and the Career Advancement of Female Academics in Higher Education: A Case Study of the University of KwaZulu-Natal, South Africa. PhD thesis submission.

Ramnund-Mansingh, A. \& M. Seedat-Khan 2020. Move Over Ms. Professor! A Review of the Challenges Women Experience in Academia. Journal of Higher Education Service Science and Management 3,1: 1 - 14.

Ramsay, E. 2001. Women and Leadership in Higher Education: Facing International Challenges and Maximising opportunities. ACU Bulletin April: $14-17$.

Seedat-Khan, M., J. Ferrante, R. Smith \& Z. Jansen 2016. Sociology: A South African Perspective. Singapore: Seng Lee Press.

Skills Development Act (No 97 of 1998). Online available at:

https://www.gov.za/documents/skills-development-act

Speedy, S. 2003. Women Using Action Learning and Action Leadership. Australia: Southern Cross University.

Swanson, D.H. \& D.D. Johnston. 2003. Mothering in the Ivy-Tower: Interviews with Academic Mothers. Journal of the Association for Research on Mothering Fall/Winter 5,2: 63 - 75.

Taylor, S.K. \& M. Anderson 2012. Workplace Bullying in Higher Education:

Faculty Experiences and Responses. University of Minnesota.

Tierney, W.G. 1988. Organizational Culture in HE: Defining the Essentials. 
Journal of Higher Education 59,1:2 - 21.

https://doi.org/10.1080/00221546.1988.11778301

UKZN Annual Report 2016.

https://www.ukzn.ac.za/wp-content/uploads/2017/11/UKZN-Annual-

Report-2016.pdf

Villette, F. 2016. The Effects of Apartheid's Unequal Education System can

Still be Felt Today. https://www.iol.co.za/capetimes/news/the-effects-ofapartheids-unequal-education-system-can-still-be-felt-today-2035295

Vincent, L. 2013. Changing a University's Institutional Culture. Paper presented at the Higher Education of South Africa Colloquium on Transformation, Bloemfontein, South Africa, May 6.

West, M. 2006. Organising Women Faculty. American Association of University Professors.

Ward, K. \& L. Wolf-Wendel 2003. Academic Motherhood: Managing Complex Roles in Research Universities. Review of Higher Education Winter 27,2: 233 - 257. https://doi.org/10.1353/rhe.2003.0079

Welch, L.B. 1990. Women in Higher Education: Changes and Challenges. New York: Praeger Books.

Dr. Aradhana Ramnund-Mansingh Durban University of Technology Durban, South Africa raakheemansingh17@gmail.com

Professor Mariam Seedat-Khan CCS The University of KwaZulu-Natal Society and Social Change Durban, South Africa Seedatm@ukzn.ac.za 